\title{
Susceptibility of Atlantic halibut Hippoglossus hippoglossus to infectious pancreatic necrosis virus
}

\author{
Eirik Biering ${ }^{1}$, Frank Nilsen ${ }^{2}$, Odd Magne Rødseth ${ }^{3}$, Johan Glette ${ }^{1}$ \\ ${ }^{1}$ Institute of Marine Research, Department of Aquaculture, PO Box 1870, N-5024 Bergen Nordnes, Norway \\ ${ }^{2}$ Department of Fisheries and Marine Biology, University of Bergen, Bergen High Technology Centre, N-5020 Bergen, Norway \\ ${ }^{3}$ Intervet NorBio A/S, Bergen High Technology Centre, N-5008 Bergen, Norway
}

\begin{abstract}
Infectious pancreatic necrosis virus (IPNV), serotype N1, isolated from Atlantic halibut Hippoglossus hippoglossus, was used to bath-challenge $\left(2 \times 10^{5.0} \mathrm{TCID}_{50} \mathrm{ml}^{-1}\right.$ for $\left.1 \mathrm{~h}\right)$ Atlantic halibut fry of different sizes at 12 and $15^{\circ} \mathrm{C}$ in 3 trials. In all trials, the fry challenged at $15^{\circ} \mathrm{C}$ experienced significantly higher cumulative mortality compared to the unchallenged fry. The smallest fry (mean weight $0.1 \mathrm{~g}$ ) also experienced significantly higher mortality compared to the controls when infected at $12^{\circ} \mathrm{C}$, whilst the medium-sized fry (mean weight $1.0 \mathrm{~g}$ ) did not display any mortality when infected at this temperature. The largest fry (mean weight $3.5 \mathrm{~g}$ ) were only challenged at $15^{\circ} \mathrm{C}$, resulting in $30 \%$ cumulative mortality. All fry infected at $15^{\circ} \mathrm{C}$ and the small fry infected at $12^{\circ} \mathrm{C}$ remained IPNV positive during the entire experimental period. In contrast, the medium-sized fry infected at $12^{\circ} \mathrm{C}$ seemed to be able to clear the infection after $3 \mathrm{wk}$. Moribund and diseased fry showed clinical signs such as distended stomach and uncoordinated swimming. Pathological findings included necrosis of the liver, kidney and intestine, but the pancreatic tissue was unaffected. Immunohistochemistry revealed strong positive reactions to IPNV in the livers of challenged individuals.
\end{abstract}

KEY WORDS: Infectious pancreatic necrosis virus - IPNV - Atlantic halibut

\section{INTRODUCTION}

The Atlantic halibut Hippoglossus hippoglossus is one of the most promising species for marine aquaculture in Norway (Tilseth 1990). Halibut larvae, which are poorly developed at hatching (Pittman et al. $1990 \mathrm{~b})$, are very vulnerable to both physiological stress and microbial infections. Accordingly, the main obstacle towards domestication of halibut has been high mortalities during the early life stages. Bacterial infections are believed to be a major cause of these mortalities (Bolinches \& Egidius 1987, Pittman et al. 1990a, Bergh et al. 1992, Opstad \& Bergh 1993), but infections with infectious pancreatic necrosis virus (IPNV) also contribute (Mortensen et al. 1990, Rødseth 1992). Although IPNV was originally regarded as a problem in fresh-water rearing of juvenile salmonids, there are several reports of mortalities in marine species, both wild and cultured, connected to infections with IPNV or closely related viruses (Stephens et al. 1980, Bonami et al. 1983, McAllister et al. 1983, Schutz et al. 1984). In Japan another aquatic birnavirus, yellowtail ascites virus (YAV), has caused significant mortalities among yellowtail fingerlings Seriola quinqueradiata (Egusa \& Sorimachi 1986, Fujimaki et al. 1986, Miyazaki 1986). Recently, IPNV has been associated with post-smolt mortality of Atlantic salmon in both Norway and Scotland (Krogsrud et al. 1989, Smail et al. 1992) and IPNVinduced disease has been experimentally transmitted to farmed turbot Scophthalmus maximus in France, Norway and Spain (Castric et al. 1987, Mortensen et al. 1993, Novoa et al. 1993). In Norway, IPNV has been isolated regularly from halibut since 1989 (Rodseth 1992), often in connection with acute mortalities during weaning. However, it has never been confirmed that IPNV is the primary agent causing these mortalities. 
It is well known that temperature, as well as host age at the time of infection, can influence the outcome of an IPNV infection in salmonids (Frantsi \& Savan 1971, Dorson \& Torchy 1981, McAllister \& Owens 1986). The work of Castric et al. (1987) on turbot indicates that transfer of IPNV carriers from 11 to $18^{\circ} \mathrm{C}$ can initiate a clinical outbreak of disease in this species. When 3 mo old turbot with a mean weight of $1.4 \mathrm{~g}$ were intraperitoneally injected with IPNV-Ab at $18^{\circ} \mathrm{C}, 56 \%$ died. In contrast, when 7 mo old turbot with a mean weight of $17 \mathrm{~g}$ were identically treated, no mortalities occurred. Novoa et al. (1993) reported $100 \%$ mortality of turbot with a mean weight of $2 \mathrm{~g}$ and no mortality in a group with a mean weight of $30 \mathrm{~g}$ when both groups were intraperitoneally injected with IPNV. These findings indicate that the susceptibility, as measured by mortality, of turbot towards IPNV infections decreases with age and increases with rising temperature.

The scope of the present study was to clarify whether an IPNV isolate from halibut (Mortensen et al. 1990) could induce mortality in halibut when administered by bath challenge and to examine the effect of host size and water temperature on the pathogenesis of the disease.

\section{MATERIALS AND METHODS}

Halibut. For all challenges, Atlantic halibut Hippoglossus hippoglossus were obtained from a commercial farm. The fry were transferred to 4 flat-bottomed tanks (volume: 60 l, bottom-area: $0.2 \mathrm{~m}^{2}$ ) receiving running seawater and acclimatized at $12^{\circ} \mathrm{C}$. Before challenge at $15^{\circ} \mathrm{C}$, the temperature was raised from $12^{\circ} \mathrm{C}$ over $2 \mathrm{~d}$. The fry in the first experiment (Expt A) were fed Artemia enriched with Super Selco (Artemia Systems N.V., Belgium) from the day they arrived from the farm. Weaning started $1 \mathrm{~d}$ before challenge, and during the first week the fry were fed both Artemia and commercial dry feed (FK-Marinstart, Felleskjøpet, Norway). The fry in the second and third experiments (Expts B and C) were fed only commercial dry feed.

Cell culture. Chinook salmon embryo (CHSE-214) cells (Lannan et al. 1984) were used for virus propagation, detection and titration. Cells were cultured in Eagle's minimum essential medium (EMEM) supplemented with $1 \%$ non-essential amino acids, $200 \mathrm{mM}$ L-glutamine, $100 \mu \mathrm{g} \mathrm{ml}^{-1}$ gentamicin and $10 \%$ foetal bovine serum for growth or $2 \%$ for virus propagation at $20^{\circ} \mathrm{C}$

Virus. In 1989, during a period of high mortality, IPNV was isolated from halibut fry sampled from a commercial farm in Norway (Mortensen et al. 1990). The isolate was serotyped as N1, a Norwegian serotype first described by Christie et al. (1988). The isolate was passed 3 times in CHSE-214 cells and used in all experiments

Challenge. In all tanks the water level was reduced to $30 \mathrm{l}$, and $60 \mathrm{ml}$ cell culture medium containing IPNV at a concentration of $10^{8.0} \mathrm{TCID}_{50} \mathrm{ml}^{-1}$ were added giving a final IPNV concentration in the tanks of $2 \times 10^{5.0}$ $\mathrm{TCID}_{50} \mathrm{ml}^{-1}$. Control fry were mock-infected with $60 \mathrm{ml}$ cell culture medium. After $1 \mathrm{~h}$ the water level was raised to the original level. Three experiments with fry of different sizes were carried out. In Expt A, 460 fry (mean weight $0.1 \mathrm{~g}$ ) were randomly divided into 4 groups and challenged as described above. Two groups (challenged and control) were kept at $12^{\circ} \mathrm{C}$, and 2 groups (challenged and control) were kept at $15^{\circ} \mathrm{C}$. In Expt B, 200 fry (mean weight $1.0 \mathrm{~g}$, range 0.3 to $1.5 \mathrm{~g}$ ) were randomly divided into 4 groups and challenged as described above. Expt $C$ was carried out with 2 groups of 20 fry (mean weight $3.5 \mathrm{~g}$, range 2.0 to $5.5 \mathrm{~g}$ ) each at $15^{\circ} \mathrm{C}$ only. Before each challenge and during the experiments, both diseased and sacrificed fry were assayed for virus. Samples for histological examinations were taken from all groups, and fry were also tested for bacterial infections. The number of live fry sacrificed before or during the phase of acute mortality in each experiment was subtracted from the population when calculating cumulative mortality. When moribund fry were sacrificed, either for histological examination or virus titration, these individuals were registered as dead.

Virus detection and titration. In Expts $A$ and $B$ whole fry were examined for virus. Unless otherwise specified in the text, all individuals, either diseased or sacrificed on a given day, were pooled before virus examination. In Expt $C$ the viscera were removed and examined individually. Samples were diluted 1:10 in cell culture medium and homogenized with mortar and pestle. The tissue suspension was then centrifuged for $10 \mathrm{~min}$ at $5000 \times g$ and the supernatant was sterile filtered $(0.2 \mu \mathrm{m})$. One $\mathrm{ml}$ of the filtrate was inoculated onto CHSE-214 monolayers in $25 \mathrm{~cm}^{2}$ tissue culture flasks and incubated at $20^{\circ} \mathrm{C}$. If no cytopathic effect (CPE) was observed after $7 \mathrm{~d}, 2$ blind passages were carried out in fresh cell cultures. When a supposed IPNV-negative sample was tested, this detection method was performed in parallel to titration as described below, whereas supposed IPNV-positive samples were analyzed by titration only. Titrations were performed on tissue extracts, prepared as described above, by end point dilutions on CHSE-214 cells in 96-well microtitre plates using 4 wells per dilution. Infected wells were identified $7 \mathrm{~d}$ after inoculation, and virus titres were expressed as $\mathrm{TCID}_{50} \mathrm{~g}^{-1}$ tissue. Virus was regularly reisolated and immunologically compared to the isolate used for challenge. The typing, using an ELISA with 6 monoclonal antibodies, 
was performed by Intervet NorBio A/S according to Christie \& Ness (1990).

Histological examinations. Samples were fixed for at least $15 \mathrm{~h}$ in a Karnovsky fixative, modified according to Nylund et al. (1992), dehydrated through a graded series of ethanol and then embedded in Jung Historesin (Heraeus Kulzer, Germany) as described by the manufacturer. Sections, $2.0 \mu \mathrm{m}$ thick, were cut on a Reichert-Jung Supercut, stained with Diff-Quick (Baxter, Germany) and examined by light microscopy. In Expts $A$ and $B$ the fry were fixed whole after the abdominal cavity was cut open to facilitate penetration of the fixative, whereas in Expt $C$ the fry were dissected and the viscera were removed and fixed separately.

Immunohistochemistry. Samples were fixed as described above, but were dehydrated through a graded series of acetone and embedded in Jung Historesin Plus (Heraeus Kulzer). (The sections were pretreated with trypsin as recommended in the manual for the embedding resin.) Endogenous peroxidase activity was blocked by incubation with $3 \% \mathrm{H}_{2} \mathrm{O}_{2}$ in phosphate-buffered saline [PBS ( $\mathrm{pH} 7.3)$ : $145.45 \mathrm{mM} \mathrm{NaCl}_{4} 4.80 \mathrm{mM} \mathrm{Na}_{2} \mathrm{HPO}_{4}$. $\left.2 \mathrm{H}_{2} \mathrm{O}, 1.87 \mathrm{mM} \mathrm{KH}_{2} \mathrm{PO}_{4}\right]$ for $10 \mathrm{~min}$ at $37^{\circ} \mathrm{C}$. The sections were then treated with $0.5 \%$ bovine serum albumin (BSA) in $\mathrm{PBS}$ for $30 \mathrm{~min}$ at room temperature, followed by incubation for $60 \mathrm{~min}$ at room temperature with a rabbit antiserum prepared against IPNV-N1. The antiserum was diluted 1:100 in PBS containing $0.5 \%$ BSA. The sections were then incubated with a donkey-anti-rabbit horse-radishperoxidase (HRP) conjugated serum (Amersham, UK) diluted 1:100 in PBS containing $0.5 \%$ BSA. Between all treatments, the sections were washed with PBS and then incubated for 10 min in PBS on a shaker. IPNV was identified by staining with DAKO AEC Substrate System (DAKO Corporation, USA) as described by the manufacturer. Finally the sections were counterstained with toluidine blue, and examined by light microscopy.

Bacterial examinations. Samples were taken aseptically from kidney, inoculated onto blood agar (Oxoid nutrient agar with $5 \%$ sheep blood and 15 ppt $\mathrm{NaCl}$ ) and incubated at $20^{\circ} \mathrm{C}$. The isolates were identified using API $20 \mathrm{E}$ and API $50 \mathrm{CHE}$ (bioMérieux, France).

\section{RESULTS}

\section{Mortality}

The fry challenged at $15^{\circ} \mathrm{C}$ showed the highest cumulative mortality in all experiments (Fig. 1). In both Expts $A$ and $B$ the mortality in this group was significantly higher compared to the mortality in the group challenged at $12{ }^{\circ} \mathrm{C}\left(p<0.05\right.$ and 0.001 respectively, $\chi^{2}$ contingency table test). The total mortalities of the groups challenged at $15^{\circ} \mathrm{C}$ were 100,68 and $30 \%$ in Expts A, B and C, respectively. The differences in mortality between these groups and the corresponding controls were, in the same order as above, 34 (at the

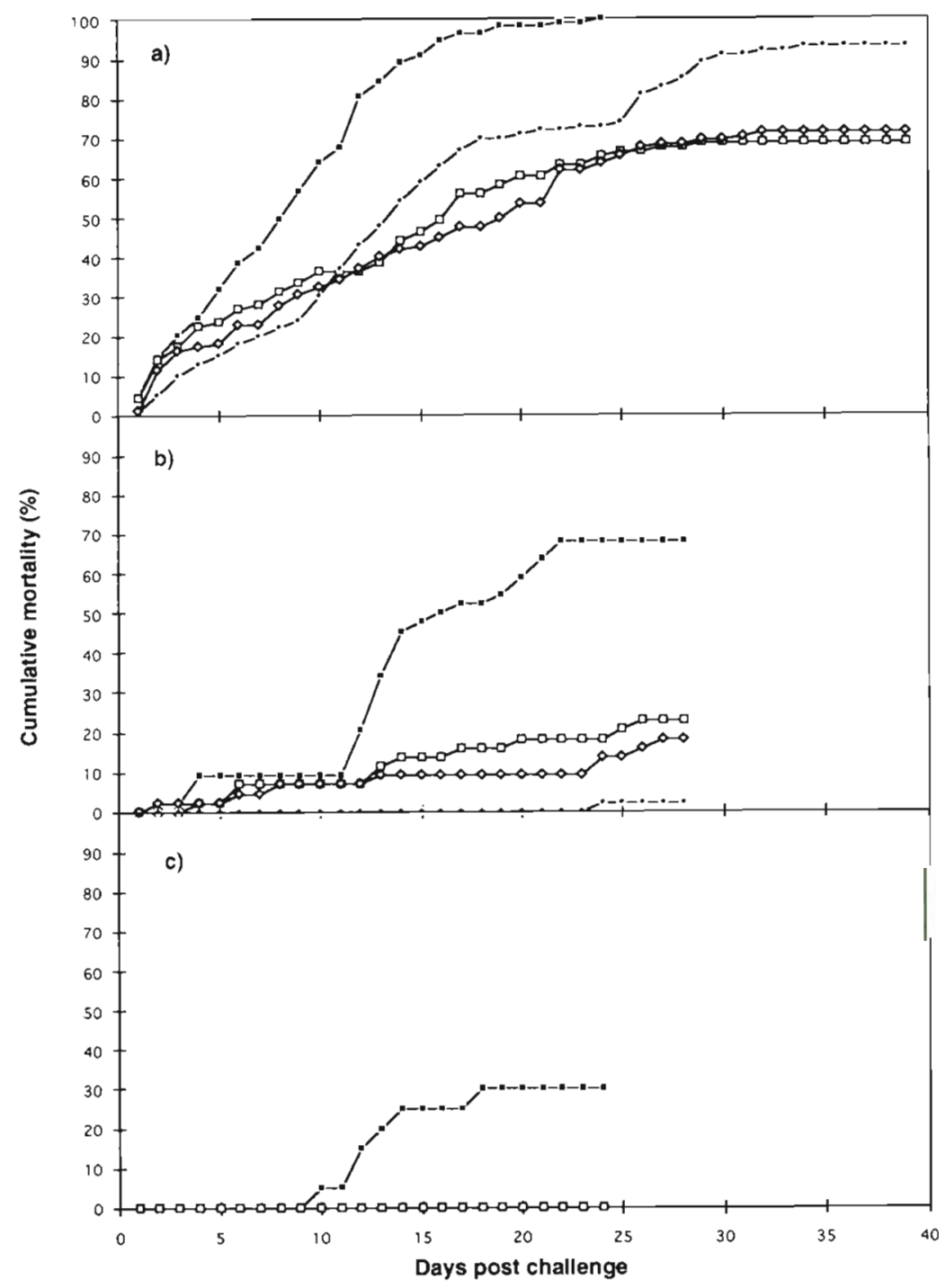

Fig. 1. Hippoglossus hippoglossus. Cumulative mortality of halibut fry challenged with IPNV at $(\bullet) 15^{\circ} \mathrm{C}$ and $(\bullet) 12^{\circ} \mathrm{C}$, and control fry mock challenged with cell culture medium at (a) $15^{\circ} \mathrm{C}$ and (o) $12^{\circ} \mathrm{C}$. (a) Expt $A$ (mean weight of fry: $0.1 \mathrm{~g}$ ); (b) Expt B (mean weight of fry: $1.0 \mathrm{~g}$ ); (c) Expt C (mean weight of fry: $3.5 \mathrm{~g}$ ) 
time of $100 \%$ mortality in the challenged group), 45 and $30 \%$ respectively. All differences between challenged groups and controls were significant ( $p<0.001$, 0.001 and 0.05 respectively, $\chi^{2}$ contingency table test). The onset of mortality occurred earlier (Day 5 postchallenge) in Expt A than in both Expts B and C (Day 12 and Day 10 respectively). The mortality of the control fish in Expts A and B may seem high, but are within the normal range for farmed halibut of this size.

When mortality in the group challenged at $15^{\circ} \mathrm{C}$, in Expt $A$, reached $100 \%$ (Day 24 ), the mortality in the parallel group challenged at $12^{\circ} \mathrm{C}$ was not significantly higher than the mortality in the controls. However, at Day 26 post-challenge the mortality in this group

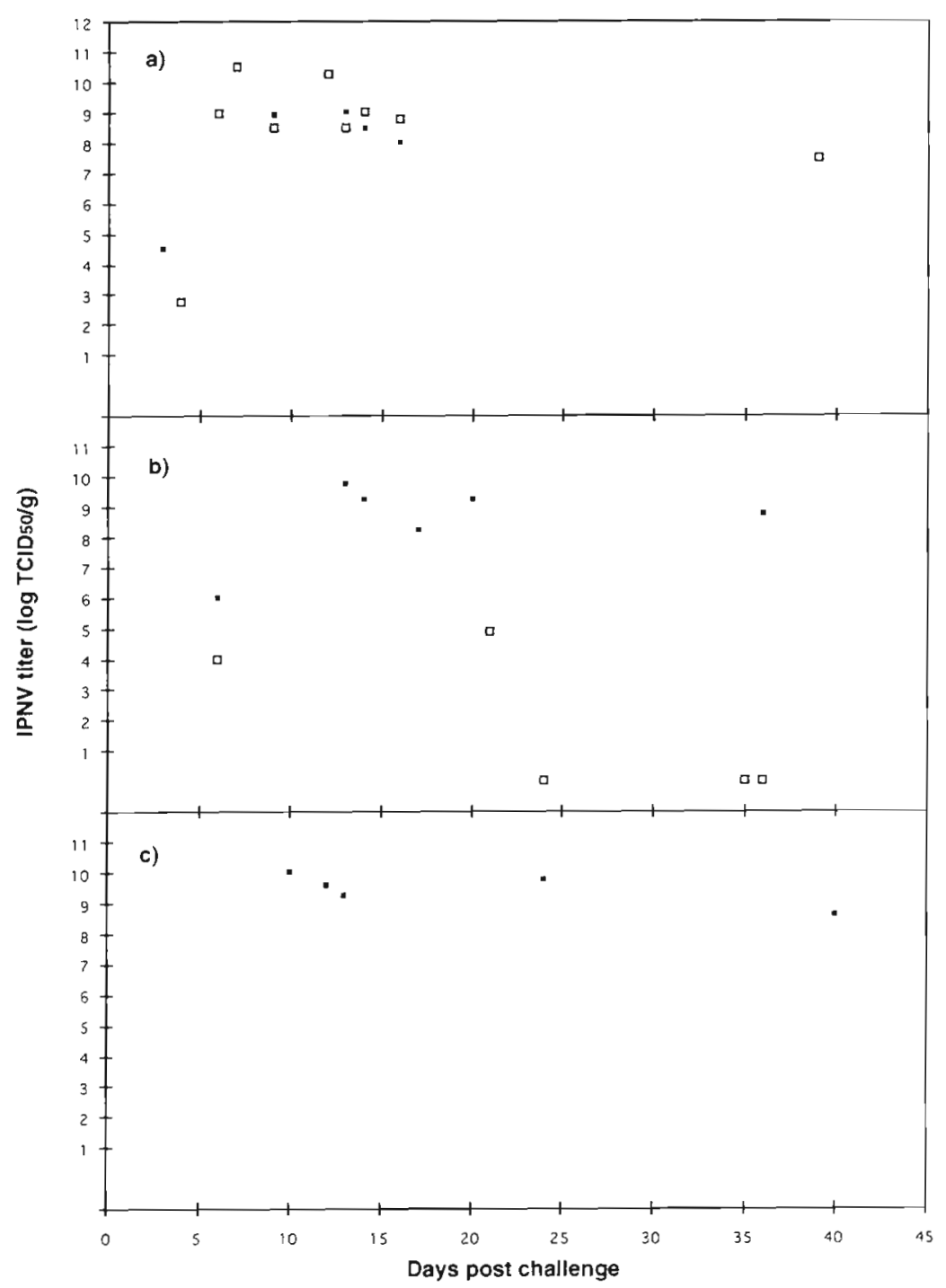

Fig. 2. Hippoglossus hippoglossus. Mean titer $\left(\log \mathrm{TCID}_{50} \mathrm{~g}^{-1}\right.$ ) of IPNV in both diseased and sacrificed halibut fry at $\left(-15^{\circ} \mathrm{C}\right.$ and (a) $12^{\circ} \mathrm{C}$ during: (a) Expt A. (mean weight of fry: $0.1 \mathrm{~g}$ ); (b) Expt B (mean weight of fry: $1.0 \mathrm{~g}$ ); (c) Expt $\mathrm{C}$ (mean weight of fry: $3.5 \mathrm{~g}$ ). Values below 1 indicate no virus detected in sample $\left(12^{\circ} \mathrm{C}\right)$ increased and at Day 34 it finally levelled at $93 \%$, significantly higher than the controls $(\mathrm{p}<0.001$, $\chi^{2}$ contingency table test).

In Expt B, the group challenged and kept at $12^{\circ} \mathrm{C}$ experienced the lowest cumulative mortality. Increased mortality in the other groups due to infections with Vibrio spp. may explain this otherwise curious observation. In Expt B, Vibrio spp. were isolated from all groups except the 1 challenged at $12^{\circ} \mathrm{C}$. During Expt A, Vibrio spp. were isolated from all groups. No control fry died during Expt $\mathrm{C}$, and bacteria were not isolated, either from challenged or from unchallenged individuals.

\section{Virus titres}

IPNV was reisolated from fry in all challenged groups (Fig. 2). In Expt A, the virus titre of pooled, diseased fry from the $12^{\circ} \mathrm{C}$ group increased from $10^{2.75}$ $\mathrm{TCID}_{50} \mathrm{~g}^{-1}$ at Day 4 post-challenge, to more than $10^{10.5} \mathrm{TCID}_{50} \mathrm{~g}^{-1}$ at Day $7 . \mathrm{A}$ similar increase in titre was observed in sacrificed fry from this group, and also in both diseased and sacrificed fry from the challenged group kept at $15^{\circ} \mathrm{C}$ When this experiment was terminated at Day 39 post-challenge, all fry from the challenged group kept at $15^{\circ} \mathrm{C}$ were dead. However, the virus titre of the surviving fry sacrificed from the group challenged at $12^{\circ} \mathrm{C}$ was $10^{6.5} \mathrm{TCID}_{50} \mathrm{~g}^{-1}$, and the titre of the diseased fry from the same group was $10^{775} \mathrm{TCID}_{50} \mathrm{~g}^{-1}$.

In Expt B, a marked effect of temperature on virus titres was found. At $12^{\circ} \mathrm{C}$ IPNV titres were equal to or lower than $10^{5.5} \mathrm{TCID}_{50} \mathrm{~g}^{-1}$ in all samples tested, and virus was not reisolated either from diseased or from sacrificed fry after Day 21. However, virus titres from fry challenged at $15^{\circ} \mathrm{C}$ ranged between $10^{50}$ and $10^{975}$ during the entire experimental period (Fig. 2). At Day 36, 6 fry from each group were sacrificed and titrated individually. All individuals from the challenged group kept at $15^{\circ} \mathrm{C}$ were IPNV positive, and the titres ranged between $10^{5.0}$ and $10^{9.5}$ TCID $_{50} \mathrm{~g}^{-1}$ IPNV was not detected in fry from the group challenged at $12^{\circ} \mathrm{C}$, or from the controls.

During Expt $C$, IPNV titres from the viscera of the challenged group ranged between $10^{7(\prime)}$ and $10^{10.25}$ TCID $_{50} \mathrm{~g}^{-1}$ throughout the entire experimental 
period, and no differences in titre were observed between diseased and sacrificed fry.

IPNV was recovered from 7 samples (17 individuals) of control fry in Expts $\mathrm{A}$ and $\mathrm{B}$, and the titres ranged between $10^{3.0}$ and $10^{6.0} \mathrm{TCID}_{50} \mathrm{~g}^{-1}$. A total of $59 \mathrm{sam}$ ples (161 individuals) of control fry were tested for the presence of virus during the 2 experiments. In addition, a total of 60 fry were tested and found negative before the challenges. IPNV was not recovered from the control group in Expt C.

\section{Clinical and histopathological findings}

A major part of the mortalities experienced by the control groups during both Expts $A$ and $B$ were probably caused by infections with various Vibrio spp. Such infections are common, and the mortalities were within the normal range for farmed halibut of this size. However, there were clear differences between the fry dying in the challenged groups and the fry dying in the control groups. Typically in the controls, moribund fry were small individuals, often anorexic, apparently at the bottom of the pecking order. Such individuals were also found among moribund fry in the challenged groups, but here also the largest, most robust looking fry were dying.

The most characteristic clinical signs of disease were distended stomach, uncoordinated swimming and trailing, white faecal casts. These symptoms were most prominent in the small fry, but they were also observed in larger individuals. The most characteristic histopathological observation was focal necrosis in the liver (Fig. 3a). Affected hepatocytes were usually hypertrophic, with a large nucleus with condensed chromatin. Sloughing, degeneration and necrosis of the epithelial cells were observed in the entire gut (Fig. 3b). In the kidney, areas with degeneration and necrosis of the haematopoietic tissue were frequently observed (Fig. 3c). In addition, the renal tubuli cells showed varying degrees of vacuolisation and degeneration. The pancreatic tissue was unaffected (Fig. 3d). We observed similar pathological changes in all experiments and at both temperatures. Pathological changes were not observed in controls. Immunohistochemistry revealed large concentrations of IPNV in the cytoplasm of liver cells (Fig. 3f, g), and in the kidney some large, mononuclear cells (possibly macrophages) were positive. The pancreatic tissue was IPNV-negative.

\section{DISCUSSION}

Bath challenge of halibut fry by IPNV induced mortality in all size groups tested, and the total mortality and pathogenesis were influenced by water temperature and fry size. Exposure to IPNV at $15^{\circ} \mathrm{C}$ resulted in higher mortality compared to exposure at $12^{\circ} \mathrm{C}$ for all sizes tested. At $12^{\circ} \mathrm{C}$, only small fry (mean weight $0.1 \mathrm{~g}$ ) seemed to develop clinical disease. Our observations of a temperature effect on mortality are in accordance with observations of Castric et al. (1987), who reported that transfer of carrier turbot from 11 to $18^{\circ} \mathrm{C}$ can provoke disease. There are several reports concerning temperature effects on IPNV infections in salmonids, but the results are not consistent. Sano (1973) reported higher mortality due to IPNV infections in rainbow trout reared and kept at 14 than at both 10 and $6{ }^{\circ} \mathrm{C}$, whereas Dorson \& Torchy (1981) observed higher mortality at 10 than at both 16 and $5.5^{\circ} \mathrm{C}$ during a challenge experiment with the same species. The temperature at which brook trout are most susceptible to infection seems to be dependent upon the virus isolate (Frantsi \& Savan 1971). These incompatible results with respect to temperature seem. to be partly, if not completely, attributable to differences in host, virus-isolate and experimental conditions.

The small fry seemed to be more susceptible to infections than the medium-sized fry (mean weight $1.0 \mathrm{~g}$ ) when infected at $12^{\circ} \mathrm{C}$, but at $15^{\circ} \mathrm{C}$ the difference in mortality between challenged fry and the corresponding controls was $45 \%$ in the medium-sized fry and $34 \%$ and $30 \%$ in the small- and large-sized fry (mean weight $3.5 \mathrm{~g}$ ) respectively. However, because the challenged fry in Expt A reached 100\% mortality before the mortality of the control group ceased, it is possible that the true mortality caused by IPNV in this experiment was higher than $34 \%$. The largest difference between challenged and unchallenged fry was $46 \%$ at Day 13 post-challenge, and if this is a more correct estimate of the true value, then our observations are in accord with previous work on both turbot and salmonids. Age- or size-dependent susceptibility to IPNV infections is well known from outbreaks of disease in farmed fry and from challenge experiments. Castric et al. (1987) and Novoa et al. (1993) report size dependent mortality of turbot fry infected with IPNV. and rainbow trout and brook trout are reported to be most susceptible to infections during early life stages (Frantsi \& Savan 1971, McAllister \& Owens 1986).

The virus titres from Expt A showed a general increase during the first week, and then levelled off between $10^{8}$ and $10^{10} \mathrm{TCID}_{50} \mathrm{~g}^{-1}$. There were no obvious differences in titres between the 2 temperatures. At both 12 and $15^{\circ} \mathrm{C}$ an infection was established during the first days post-challenge, and high virus titres were registered during the entire experimental period. In contrast, during Expt $\mathrm{B}$, infection with high titres was not established at $12^{\circ} \mathrm{C}$, and the fry seemed to clear the infection after $3 \mathrm{wk}$. During both Expts B and $\mathrm{C}$, high titres were registered from the fry challenged 


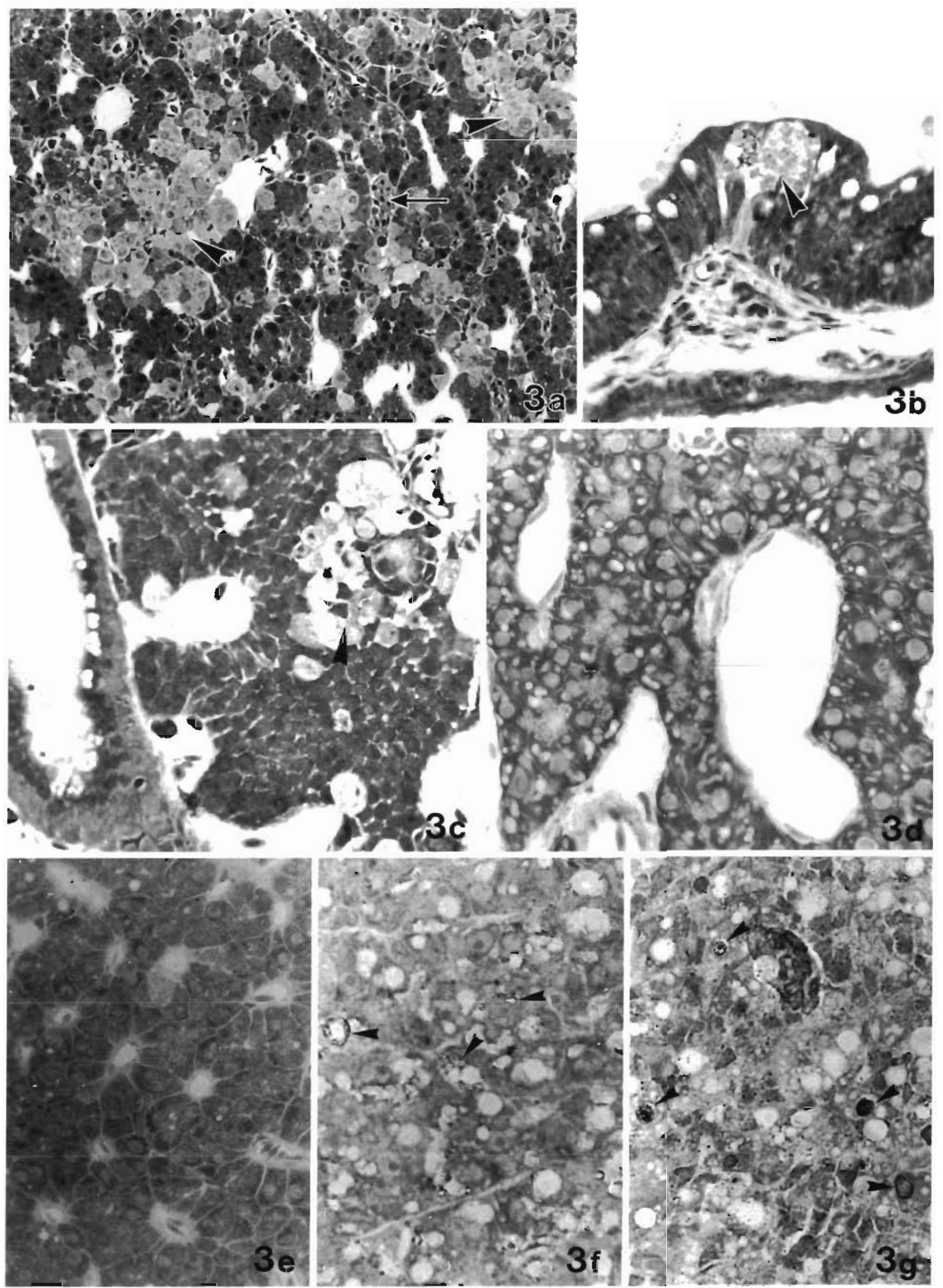


at $15^{\circ} \mathrm{C}$. These facts clearly agree with the mortalitypattern, since a high-titre infection was established only in the groups that showed significantly higher mortality due to challenge with IPNV

The observed pathological changes in the liver and kidney, as well as the absence of any pathology of the pancreatic tissue are in agreement with the findings of Castric et al. (1987) and Novoa et al. (1993) on turbot., while our observations on necrosis of the gut and stomach have not been previously described in flatfish. However, the first report on IPNV infections in salmonids (M'Gonigle 1941) names the condition acute catarrhal enteritis. Mortensen et al. (1993) report necrosis and positive immunohistochemical reactions to IPNV in exocrine pancreas of naturally diseased turbot and no pathological changes in experimentally infected fry. In addition, Rødseth (1992) reported necrosis of exocrine pancreas in naturally infected halibut. Neither of these findings are in agreement with the present work. Consequently, the different reports existing on IPNV pathology in flatfish are not consistent, and there are evidently differences attributable to both host and virus isolate, but also differences between natural and experimental infection. Reports from Japan concerning the pathology of yellowtail ascites virus (YAV) infections of yellowtail fingerlings (Egusa \& Sorimachi 1986, Fujimaki et al. 1986, Miyazaki 1986) agree with our observations, except for the presence of pancreatic necrosis. The isolate used for challenge in the present work had been passed 3 times in CHSE-214 cells. Passes in tissue culture may change the tissue tropism of an isolate, and this might explain the absence of pancreatic necrosis in challenged individuals. Although the isolate was serotyped as IPNV-N1, a more correct nomenclature would be aquatic birnavirus, as an IPNV strain will by definition cause pancreatic necrosis.

It is possible that the infections with Vibrio spp observed during Expts A and B may have contributed to the pathology, but 2 facts make this rather unlikely. Firstly, the pathological picture observed was very similar in all 3 experiments, and bacteria were not isolated during Expt C. Secondly, we did not find any signs of bacterial infection in any of the specimens examined histologically.

The occurrence of IPNV-positive individuals in the control groups of small and medium-sized fry is obvi- ously a complicating factor, and these infections may have contributed to the mortality during the challenges. The source of the infections is unknown, but it is likely that a number of fry were carriers when they arrived from the commercial farm. These individuals escaped detection during the pre-challenge virus screenings, either because the number of fry tested was too small or the virus titre was too low for the current diagnostic procedures. The isolates appeared similar to the one used for the challenges, all were classified as IPNV-N1 when compared immunologically. Nevertheless, it is possible that the isolates are non-pathogenic for halibut, but further challenge experiments are necessary to clarify this. However, the present work demonstrates significant differences between challenged and unchallenged halibut in spite of virus positive control fish. Repeating the experiments with, hopefully, pathogen free fry would be very time consuming, and we believe the likelihood of gaining additional information is small. It is the authors' opinion, given the present state of halibut rearing, that the possibilitiy of obtaining experimental fish free of both IPNV and Vibrio spp. is very small.

In conclusion, our observations on the effect of temperature and fry size on mortality and persistence of IPNV infection, indicate that farmed halibut ready for weaning $(0.1 \mathrm{~g})$ are susceptible to infection at both 12 and $15^{\circ} \mathrm{C}$. Older fry $(1.0$ and $3.5 \mathrm{~g})$ seem to be susceptible only at $15^{\circ} \mathrm{C}$. Stress caused by suboptimal temperature followed by impaired ability to cope with an infection is the most obvious explanation. Investigations by Bjørnsson (1993) concerning optimal temperatures for growth and feed conversion of Atlantic halibut demonstrate decreasing optimal temperature for increasing weight, and estimate the temperature for optimal growth of $26 \mathrm{~g}$ halibut to be $13^{\circ} \mathrm{C}$ or higher. These conclusions are supported by other works (Aune \& Pittman 1994, Aune et al. 1994, Hallaråker et al. in press, Hole \& Pittman in press). There are no reports on the effect of temperature on Atlantic halibut in relation to immunological parameters, but the upper limit for the fry used in the present work is approximately $16^{\circ} \mathrm{C}$ (Karen Pittman, Department of Fisheries and Marine Biology, University of Bergen, pers. comm.). Temperatures between 12 and $15^{\circ} \mathrm{C}$ are relevant in commercial farming of halibut at the onset of weaning (Grethe Adoff, Stolt Sea Farm A/S, pers. comm.). Since this period appears to be the most

Fig. 3. Hippoglossus hippoglossus. (a) to (d) Toluidine blue stained histological sections from halibut fry challenged with IPNV. (a) Typical pathological changes in the liver of halibut infected with IPNV. Arrowheads indicate focal liver necrosis, and arrow indicates congestion, i.e. blood-filled space without any endothelial lining (original magnification: $\times 200$ ). (b) Necrotic area (arrowhead) in the intestinal epithelium (original magnification: $\times 540$ ). (c) Necrosis in haematopoietic tissue of the kidney (arrowhead). Also note vacuolization of the renal tubuli cells (original magnification: $\times 720$ ). (d) Pancreatic tissue from the same fry as in (a). No destruction of the tissue is observed (original magnification: $\times 400)$. (e) to $(g)$ Immune stained slides from halibut liver (original magnification: $\times 625$ ). (e) Liver from fry not challenged with IPNV. No reactions against IPNV are seen. (f), (g) Liver from fry challenged with IPNV showing positive reaction against the virus. Arrowheads indicate positive cells 
critical with respect to disease outbreaks, it would be worthwhile considering lower temperatures as a preventive approach towards IPNV infections.

Acknowledgements. The authors thank Hari Rudra and Kari Andersen for excellent technical assistance, and Øivind Bergh for comments on the manuscript. Thanks to Stolt Sea Farm A/S for providing the halibut, and to Dr. Karen Elina Christie at Intervet NorBio A/S for performing the serotyping. This work was supported by The Norwegian Research Council.

\section{LITERATURE CITED}

Aune, A., Hole, G., Pittman, K. (1994). Growth in juvenile halibut from 2 to 500 grams: a changing temperature optimum and some effects of light. Bordeaux Aquaculture, March 23-25, 1994

Aune, A., Pittman, K. (1994). The effect of early environment on optimal temperature for growth in juvenile halibut. Bordeaux Aquaculture, March 23-25, 1994

Bergh, Ø., Hansen, G. H., Taxt, R. E. (1992). Experimental infection of eggs and yolk sac larvae of halibut, Hippoglossus hippoglossus L. J. Fish Dis. 15: 379-391

Bjornsson, B. (1993). Optimal temperature of immature halibut (Hippoglossus hippoglossus): effects of size. Comm. Meet. int. Coun. Explor. Sea C.M.-ICES/1993/F:37

Bolinches, J., Egidius, E. (1987). Heterotrophic bacterial communities associated with the rearing of halibut (Hippoglossus hippoglossus L.) with special reference to Vibrio spp. J. appl. Ichthyol. 3: 165-173

Bonami, J R., Cousserans, F., Weppe, M., Hill, B. J. (1983). Mortalities in hatchery-reared sea bass fry associated with a birnavirus. Bull. Eur. Ass. Fish Path. 3: 41

Castric, J., Baudin-Laurencin, F., Coustans, M. F., Auffret, M. (1987). Isolation of infectious pancreatic necrosis virus, $\mathrm{Ab}$ serotype, from an epizootic in farmed turbot, Scophthalmus maximus. Aquaculture 67: 117-126

Christie, K. E., Håvarstein, L. S., Djupvik, H. O., Ness, S., Endresen, C. (1988). Characterisation of a new serotype of infectious pancreatic necrosis virus isolated from Atlantic salmon. Arch. Virol. 103: 167-177

Christie, K. E., Ness, S. (1990). Infectious pancreatic necrosis virus in Norway: partial serotyping by monoclonal antibodies. J. Fish Dis. 13: 323-327

Dorson, M., Torchy, C. (1981). The influence of fish age and water temperature on mortalities of rainbow trout, Salmo gairdneri Richardson, caused by a European strain of infectious pancreatic necrosis virus. J. Fish Dis. 4: 213-221

Egusa, S., Sorimachi, M. (1986). A histopathological study of yellowtail ascites virus (YAV) infection of fingerling yellowtail, Seriola quinqueradiata. Fish Path. 21: 113-121

Frantsi, C., Savan, M. (1971). Infectious pancreatic necrosis virus - temperature and age factors in mortality. J Wildl Dis. 7: $249-255$

Fujimaki, Y., Hattori, K., Hatai, K., Kubota, S. S. (1986). A light. and electron microscopic study on yellowtail fingerlings with ascites. Fish Path. 21. 105-111

Hallaråker, H., Folkvord, A., Pittman, K., Stefansson, S. (in press). Growth of $0+$ halibut (Hippoglossus hippoglossus) related to temperature, light and feeding regime. In: ICES Symposium on Mass Rearing of Juvenile Fish, Bergen, June 21-23, 1993

Hole, G. Pittman, K. (in press). The effects of temperature and light on growth in juvenile halibut. In: ICES Symposium on Mass Rearing of Juvenile Fish, Bergen, June 21-23, 1993
Krogsrud, J., Håstein, T., Rønningen, K. (1989). Infectious pancreatic necrosis virus in Norwegian fish farms. In Ahne, W. Kurstak, E. (eds.) Viruses of lower vertebrates. Springer-Verlag, Berlin, p. 284-291

Lannan, C. N., Winton, J. R., Fryer, J. L. (1984). Fish cell lines establishment and characterization of nine cell lines from salmonids, In Vitro 20: 671-676

McAllister, P. E., Newman, M. W., Sauber, J. H., Owens, W. J. (1983). Infectious pancreatic necrosis virus: isolation from southern flounder, Paralichthys lethostigma, during an epizootic. Bull. Eur. Ass. Fish Path. 3: 37-38

McAllister, P. E., Owens, W. J. (1986). Infectious pancreatic necrosis virus: protocol for a standard challenge to brook trout. Trans. Am. Fish. Soc. 115: 466-470

M'Gonigle, R. H. (1941). Acute catarrhal enteritis of salmonid fingerlings. Trans. Am. Fish. Soc. 70: 297-303

Miyazaki, T. (1986). A histopathological study on serious cases with viral ascites of yellowtail fingerling occurred in Mie prefecture. Fish Path. 21: 123-127

Mortensen, S. H., Evensen, Ø., Rødseth, O. M., Hjeltnes, B. K. (1993). The relevance of infectious pancreatic necrosis virus (IPNV) in farmed Norwegian turbot (Scophthalmus maximus). Aquaculture 115: 243-252

Mortensen, S. H., Hjeltnes, B., Rødseth, O., Krogsrud, J., Christie, K. E. (1990). Infectious pancreatic necrosis virus, serotype N1, isolated from Norwegian halibut (Hippoglossus hippoglossus), turbot (Scophthalmus maximus) and scallops (Pecten maximus). Bull. Eur. Ass. Fish Path 10: 42

Novoa, B., Figueras, A., Puentes, C. F., Ledo, A., Toranzo, A. E. (1993). Characterization of a birnavirus isolated from diseased turbot cultured in Spain. Dis. aquat. Org. 15: 163-169

Nylund, A., Økland, S., Bjørknes, B. (1992). Anatomy and ultrastructure of the alimentary canal in Lepeophtheirus salmonis (Copepoda: Siphonostomatoida). J. crust. Biol. 4: $423-437$

Opstad, I., Bergh, $\varnothing$. (1993). Culture parameters, growth and mortality of halibut (Hippoglossus hippoglossus L.) yolk sac larvae in upwelling incubators. Aquaculture 109: 1-11

Pittman, K., Bergh, Ø., Opstad, l., Skiftesvik, A. B., Skjolddal, L., Strand, H. (1990a). Development of eggs and yolk sac larvae of halibut (Hippoglossus hippoglossus L.). J. appl. Ichthyol. 6: 142-160

Pittman, K., Skiftesvik, A. B., Berg, L. (1990b). Morphological and behavioural development of halibut. Hippoglossus hippoglossus (L.) larvae. J. Fish Biol. 37: 455-472

Rødseth, O. M. (1992). Sykdommer hos flatfisk i oppdrett. Norsk Fiskeoppdrett. 2: 22-25

Sano, T. (1973). The current preventive approach to infectious pancreatic necrosis (IPN) in Japan. In: Dill, W. A. (ed.) Symposium on the major communicable fish diseases in Europe and their control. EIFAC/T17 (Suppl. 2), Amsterdam, p. 71-78

Schutz, M., May, E. B., Kraeuter, J. N., Hetrick, F. M. (1984). Isolation of infectious pancreatic necrosis virus from an epizootic occurring in cultured striped bass, Morone saxatilis (Walbaum). J. Fish Dis. 7: 505-507

Smail, D. A., Bruno, D. W., Dear, G., McFarlane, L. A., Ross, K. (1992). Infectious pancreatic necrosis (IPN) virus Sp serotype in farmed Atlantic salmon, Salmo salar L., postsmolts associated with mortality and clinical disease. J. Fish Dis. 15: 77-83

Stephens, E. B., Newman, M. W., Zachary, A. L., Hetrick, F. M. (1980). A viral aetiology for the annual epizootics of Atlantic menhaden Brevoortia tyrannus (Latrobe) in Chesapeake Bay. J. Fish Dis. 3: 387-398

Tilseth, S. (1990). New marine fish species for cold-water farming. Aquaculture 85: 235-245 